\title{
Classification of Canal Control Algorithms
}

\author{
Pierre-Olivier Malaterre ${ }^{1}$, David C. Rogers ${ }^{2}$, Jan Schuurmans ${ }^{3}$
}

Key words: Automation, Characterization, Classification, Control Algorithm, Controller, Irrigation Canal, Regulation.

\begin{abstract}
Different control algorithms for the regulation of irrigation canals have been developed and applied throughout the world. Each of them can be characterized according to several criteria, among which are: the considered variables (controlled, measured, control action variables), the logic of control (type and direction), and the design technique. The following text presents definitions of these terms and a classification of the algorithms detailed in the literature. To summarize and compare algorithms, a structured table of the main published canal control algorithms is presented.
\end{abstract}

\section{INTRODUCTION}

A control system is an elementary system (algorithm + hardware) in charge of operating canal cross structures, based on information from the canal system. This information may include measured variables, operating conditions (e.g. predicted withdrawals) and objectives (e.g. hydraulic targets). Boundaries of the control system are outputs of the sensors placed on the canal system, and inputs to the actuators controlling the cross structures. The following text presents definitions and a classification of canal control algorithms developed or used in the world. Hardware aspects will be presented in a separate paper (Goussard et al.).

The difficulty presented by the classification of canal control algorithms is due to the different ways of characterizing them (e.g. controlled variables, configuration of field implementation, communication management, design technique, alarm management, location along a canal). Among all possible criteria, one wants to retain those, in minimum number, that allow characterization of the hydraulic behavior, the performance and the constraints of the various canal control algorithms. We choose to retain the following three essential criteria: considered variables, logic of control, and design technique. Sub-criteria will be defined to refine them.

These different terms are defined, discussed and illustrated in the following sections. The order of the three criteria is not linked to any priority of interest. Depending on technical background and areas of responsibility, different people may have different levels of interest in the three criteria. Civil and hydraulic engineers may be more concerned with the considered variables, while control engineers are more concerned with the design technique.

1 Research Engineer, PhD, Cemagref, BP 5095, 34033 Montpellier Cedex 1, France

2 Hydraulic Engineer, Bureau of Reclamation, PO Box 25007, D-8560, Denver, Colorado 80225, USA

3 PhD Student, Delft University of Technology, PO Box 5048, 2600 GA Delft, The Netherlands 


\section{CONSIDERED VARIABLES}

Variable location is given in reference to a pool (a pool is a portion of a canal, situated between two control devices) and not to a structure (e.g. upstream end, intermediate or downstream end of a pool). This avoids confusion in the case of a multivariable control algorithm, where a variable can be controlled by both upstream and downstream structures. Three types of variables are considered in control algorithms: controlled, measured and control action variables.

\section{Controlled variables}

Controlled variables are target variables controlled by the control algorithm. Examples are water level at the upstream end of a pool $\left(\mathrm{y}_{\mathrm{up}}\right)$, water level at the downstream end of a pool $\left(\mathrm{y}_{\mathrm{dn}}\right)$, flow rate at a structure $(\mathrm{Q})$, volume of water in a pool $(\mathrm{V})$, and weighted water level (e.g. a $\mathrm{y}_{\mathrm{up}}+\mathrm{b} \mathrm{y}_{\mathrm{dn}}$ ). Controlled variables are not necessarily directly measurable.

Control theory speaks of "tracking" when these target variables are time dependent. Some authors use the term "regulation" in a general sense, for all types of targets (constant or variable), while others only in the case of a null constant target. In this article, the term "regulation" is used in a general sense and "tracking" to refer to the time dependent feature of the target.

\section{Discharges}

The needs of irrigation canal users are defined mainly in terms of discharge. For example, agricultural needs are expressed in terms of given discharges delivered to a plot, to a secondary canal, or to a pumping station; environmental needs as tailend discharge, or minimal discharge; urban needs as discharges delivered to a house or to a city water filtration plant; and industrial needs as discharges delivered to a factory. Natural or artificial storage reservoirs are sometimes available (e.g. soil maximum water storage, lateral or on-line reservoir, basin of a water filtration plant, volume stored into the canal pools). Users' needs can then be defined in a more flexible way, in terms of volume distributed over a time period. In this case, the controlled variable is no longer a given value of discharge, but a volume, which is the integral of a discharge over a given time period. Discharge fluctuations are then authorized, and neutralized by the capacity of the storage reservoirs. However, these reservoirs are expensive and of limited sizes, and constraints of distribution never suppress needs expressed in terms of discharge.

Consequently, all free surface hydraulic systems must be managed, directly or indirectly, in order to satisfy users' demands in discharge. Considering the nature of the physical phenomenon at stake (gravity open channel flow from upstream to downstream), these demands in discharge can be satisfied only from the source situated at the upstream end of the system, by draining the upstream reservoirs. GPC (Sawadogo et al. 1991a, 1991b, 1992a, 1992b and 1992c, Rodellar et al. 1993), CACG (Piquereau et al. 1982 and 1984, Grosclaude et al. 1985, Verdier 1986, Tardieu 1988, Barbet 1990, Rey 1990, Trouvat 1991, Hurand et al. 1993), and SIMBAK (Chevereau 1991) are examples of regulation methods controlling discharges. 
Contrary to discharges, water levels can be easily measured in free surface canals and rivers. Furthermore, constraints of feeding gravity turnouts, stability of canal banks, efforts to reduce weed growth, constitution of intermediate water storage volumes, and risks of overflow are expressed in terms of water levels. Controlled water levels "y" can be upstream ( $\mathrm{y}_{\mathrm{up}}$, Figure 1), downstream ( $\mathrm{y}_{\mathrm{dn}}$, Figure 2), or intermediate inside the pool $\left(\mathrm{y}_{\text {in }}\right.$, Figure 3). The location of controlled variables in a pool is indicative of hydraulic behavior (e.g. available storage volume) and civil engineering constraints (e.g. bank slopes). On Figures 1 and 2, controlled water level values are equal at null and maximum discharges. This is not always the case (e.g. GEC Alsthom Gates). The corresponding water level difference is called "decrement". Operational characteristics are very different depending on the location of "y".
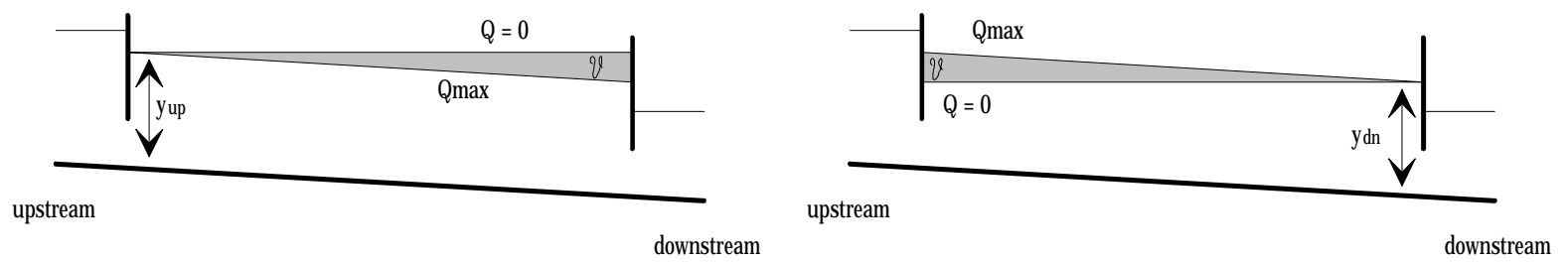

FIG. 1. Control of the upstream level of a FIG. 2. Control of the downstream level of pool. a pool.

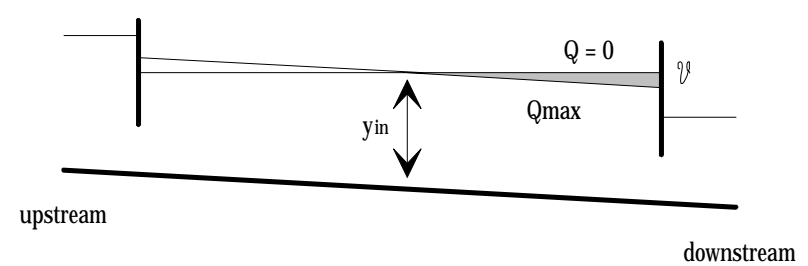

FIG. 3. Control of an intermediate water level.

One of the advantages of controlling upstream water levels is that a storage volume $\mathrm{V}$ is available between the null discharge volume and the maximum discharge volume. It allows for rapid response to unforeseen demands of turnouts or downstream reaches and for storing water in case of a consumption reduction. But canal banks have to be horizontal, which is expensive. AVIS and AVIO gates (GEC Alsthom 1975-79 and 1981, Goussard 1993), and LittleMan downstream controller (developed by the USBR, Zimbelman 1987) are examples of such methods.

When downstream water levels are controlled, canal banks can follow the field natural slope, which reduces construction costs. But, no storage volume is available between the null discharge volume and the maximum discharge volume. In fact, pool volumes change in the opposite direction from the direction that will help satisfy downstream demand changes. Therefore, the system cannot respond rapidly to unforeseen demands. The excess water cannot be stored locally and is "lost" in the downstream pools. Supply flow changes must overcompensate in order to match downstream demand changes and to establish new pool volumes. AMIL gates (GEC Alsthom 1975-79 and 1981, Goussard 1993), ELFLO (Shand 1971, Buyalski et al. 1979), CARDD (Burt 1983), LittleMan upstream controller (Zimbelman 1987), PIR (Deltour 1992), PID (developed by UMA Engineering and applied at Imperial Valley, USA), PI (developed by Sogreah and applied at Kirkuk, Iraq), Zimbelman (developed by Zimbelman in 1981, Zimbelman 1987) are examples of downstream water level control. 
Controlling a particular intermediate water level, close to the middle of the pool, is equivalent to controlling the volume stored in the pool. This water level can be measured directly (no example has been found in the literature), or can be obtained as a linear combination of an upstream and a downstream water level (e.g. BIVAL). Controlling an intermediate water level is a compromise between the two previous options, in terms of construction cost and availability in storage volume V. Indeed, banks have to be horizontal only downstream from the controlled intermediate water level. But, one or several distant water levels have to be measured, which increases measurement and telemetry requirements. BIVAL (developed by Sogreah, Zimbelman 1987, Chevereau 1991) is the only example of such a method.

\section{Volumes}

In this case, controllers are less sensitive to perturbations, but response times are increased (Framji et al. 1978). These methods are applicable to irrigation canals with important storage volumes, and equipped with turnouts whose feeding is not dependent on water levels in the main canal (e.g. pumping stations). Dynamic Regulation (Coeuret 1977, Lefebvre 1977, Deltour 1988), and Controlled Volumes (Buyalski 1991) are examples of such methods.

\section{Measured variables}

Measured variables, also called inputs of the control algorithm, are the variables measured on the canal system. Examples are water level at the upstream end of a pool $\left(\mathrm{y}_{\text {up }}\right)$, water level at the downstream end of a pool $\left(\mathrm{y}_{\mathrm{dn}}\right)$, water level at an intermediate point of a pool $\left(\mathrm{y}_{\mathrm{in}}\right)$, flow rate at a structure $(\mathrm{B})$, and setting of a structure (G).

Measured variables on irrigation canals are generally water levels (e.g. ELFLO, PIR). In some cases, measured variables can be discharges (e.g. CACG). Discharge can be measured with flow meters (based in general on the measure of one or several flow velocities, with a propeller, an ultrasonic or electromagnetic device), measurement flumes using water level measurement to compute $\mathrm{G}(\mathrm{z})$, through a cross structure equation $\mathrm{Q}\left(\mathrm{z}_{1}, \mathrm{z}_{2}, \mathrm{G}\right)$, or a local control section rating curve $\mathrm{Q}(\mathrm{z})$ with a sufficient precision. When such an equation exists, it is assumed that a discharge $Q$ is really measured, whatever the process used to obtain it, even if it is calculated from one or several water level measurements. Finally, measured variables can be volumes, evaluated by measuring several water levels along the canal, or by evaluating input - output discharge balance (e.g. Dynamic Regulation).

\section{Control action variables}

Control action variables (U), also called outputs of the control algorithm, are variables issued from the control algorithm and supplied to the cross structures' actuators. They are either gate positions $(G)$ or flow rates $(\mathrm{Q})$. In this latter case, another algorithm transforms the flow rate into a gate position. This algorithm is important from hydraulic and control points of view, and is considered as a separate control algorithm. Remark: control action variables $\mathrm{G}$ or $\mathrm{Q}$ can be considered as absolute 
values, relative values (relative to a reference state) or as incremental values (to be added to the value of the previous time step).

Gate position (G) has the advantage of taking into account the complex dynamics linking this position with the local discharge and upstream and downstream water levels. These dynamics are important and it can be hazardous not to take them into account (e.g. LQR Cemagref, ELFLO consider $\mathrm{G}$ as the control action variable). Considering discharge as the control action variable allows for decoupling of the different subsystems. This is interesting when monovariable controllers are used in series (e.g. Dynamic Regulation, PIR). However, the dynamics of the local controller linking the discharge (control action variable $\mathrm{Q}$ ) to the gate position (control action variable G) are not taken into account in the global controller. Therefore, the quality of the behavior of the global controller cannot be assessed, since important dynamics are neglected in the design of the controller. If the control action variable (U) is a discharge $(\mathrm{Q})$, it is necessary to convert it into gate position $(\mathrm{G})$, applicable to the system. This conversion can be done through the inversion of the device static equation $Q\left(z_{1}, z_{2}, G\right)$, or by a local dynamic controller (e.g. PID controller).

Remark: I/O structure is the number of inputs and outputs considered by the control algorithm. A control algorithm is said $\mathrm{nImO}$ when it has $\mathrm{n}$ inputs (measured variables) and $\mathrm{m}$ outputs (control action variables). Special names are given in specific cases: SISO (Single Input, Single Output, if $n=m=1$ ), MISO (Multiple Inputs, Single Output, if $n>1$ and $m=1$ ), and MIMO (Multiple Inputs, Multiple Outputs, if $n$ and $m>1$ ). This structure has an influence on the techniques that could be used for the design of the algorithm.

\section{LOGICS OF CONTROL}

The logic of control refers to the type and direction of the links between controlled variables and control action variables.

\section{Type}

The control algorithm uses either feedback control (FB, also called closed-loop control), feedforward control ( FF, also called open-loop control) or a combination ( $F B+F F)$.

\section{Feedback control}

In a feedback control algorithm, the controlled variables $(\mathrm{Y})$ are measured or directly obtained from measurements. Any deviation from the target $\left(\mathrm{Y}_{\mathrm{c}}\right)$ is fed back into the control algorithm in order to produce a corrective action U (Figure 4). Perturbations (P), even if unknown, are taken into account indirectly, through their effects on the output $\mathrm{Y}$ of the system. In control theory, this concept is essential since it links a control action variable $\mathrm{U}$ to a controlled variable $\mathrm{Y}$. 


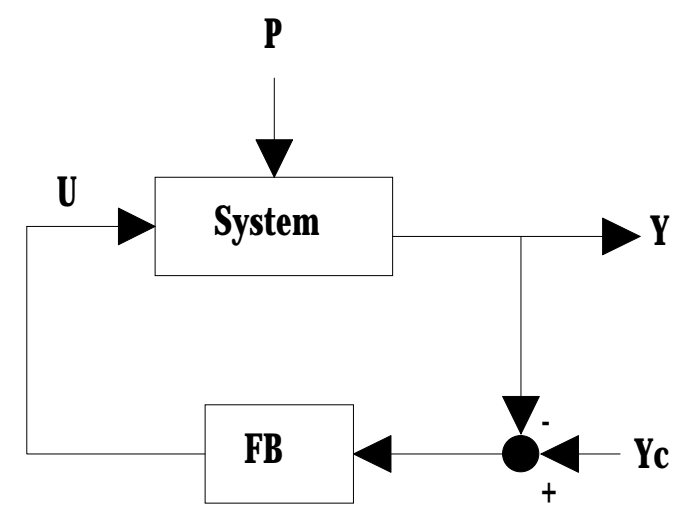

FIG. 4. Feedback control.

Feedback control can be applied to all the controlled variables: discharge, water level and volume:

- Examples of feedback control in discharge are GPC (Sawadogo 1992a, Rodellar et al. 1993), CACG (Piquereau et al. 1982), CARA (Marzouki 1989, Roux 1992, Kosuth et al. 1992), Liu et al. 1994, CARAMBA (De Leon 1986), IMTA-Cemagref (De Leon et al. 1992).

- Examples of feedback control in water level are AMIL, AVIS, AVIO gates, LittleMan, ELFLO (Shand 1971), CARDD (Burt 1983), Zimbelman (1981), BIVAL, PI developed by Sogreah, PID (Chevereau 1991), PID developed by UMA Engineering, PIR (Deltour 1992), Liu et al. 1994, Cemagref-IMTA (Chavez et al. 1994).

- Examples of feedback control in volume are Dynamic Regulation (SCP) and Controlled Volumes (USBR).

For complex processes, like dead time processes (processes with time delays, Kuanyi 1989), feedback control has limitations. In the case of irrigation canals, time delays between upstream control actions and downstream controlled variables are important (a few minutes to several hours). A single feedback control can function correctly only if important storage volumes are available. Indeed, control delay is, at least, equal to the system delay. But storage volumes imply high construction costs. The quality of the control can be considerably improved by adding a feedforward control component (Shinskey 1988).

\section{Feedforward control}

In a feedforward control algorithm, the control action variables $U$ are computed from targeted variables $Y_{c}$, perturbation estimations $\widehat{P}$ and process simulation (Figure 5). Feedforward control usually improves control performance when few unknown perturbations occur in the canal system. The feedforward control can compensate inherent system time delays by anticipating users' needs. These needs have to be estimated as precisely as possible. They should take into account climatic, agronomic, and sociological data, as well as records of the water consumption of previous weeks or seasons (Perrin 1989). 


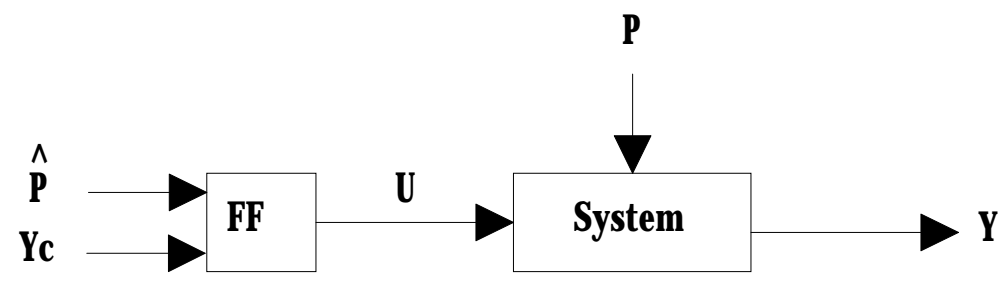

FIG. 5. Feedforward control.

Feedforward control can be applied to all the controlled variables: discharge, water level and volume. Some examples are quoted both in control of discharges and of water levels. For example, the dynamic wave model calculates simultaneously these two types of variables.

- Examples of feedforward control in discharge are given depending on the calculation method used:

- By model inversion: kinematic wave or pure delay (CARA, Roux 1992), diffusive wave (CACG, Sawadogo 1992a), dynamic wave (Chevereau 1991: SIMBAK, O'Laughlin 1972, Liu et al. 1992, USBR 1979 and Falvey 1987: Gate Stroking). These different methods are studied and compared by Chevereau (1991).

- By optimization (Najim 1981, Sabet et al. 1985, Tomicic 1989, Khaladi 1992, Lin et al. 1992).

- Example of feedforward control in water level are:

- By inversion of the dynamic wave model (O'Laughlin 1972, Liu et al. 1992, USBR 1979, Falvey 1987).

- By optimization (Tomicic 1989, Khaladi 1992, Lin 1992).

- By simulation (Malaterre 1989, Baume et al. 1993).

- Sabet et al. (1985) is an example of a feedforward control in volume.

Feedforward control is generally insufficient by itself, due to model errors, perturbation estimation errors, and unknown perturbations, and must be combined with feedback control to compensate for these errors.

\section{Combination of both}

Both feedback and feedforward control have advantages and limitations. For these reasons, the combination of feedforward and feedback control is often used (Figure 6). For a multivariable system (with several control action and controlled variables), several controllers with different logics of control can be combined. For example, discharges can be controlled in feedforward control and water levels in feedback control. Therefore, some regulation methods may appear in several categories.

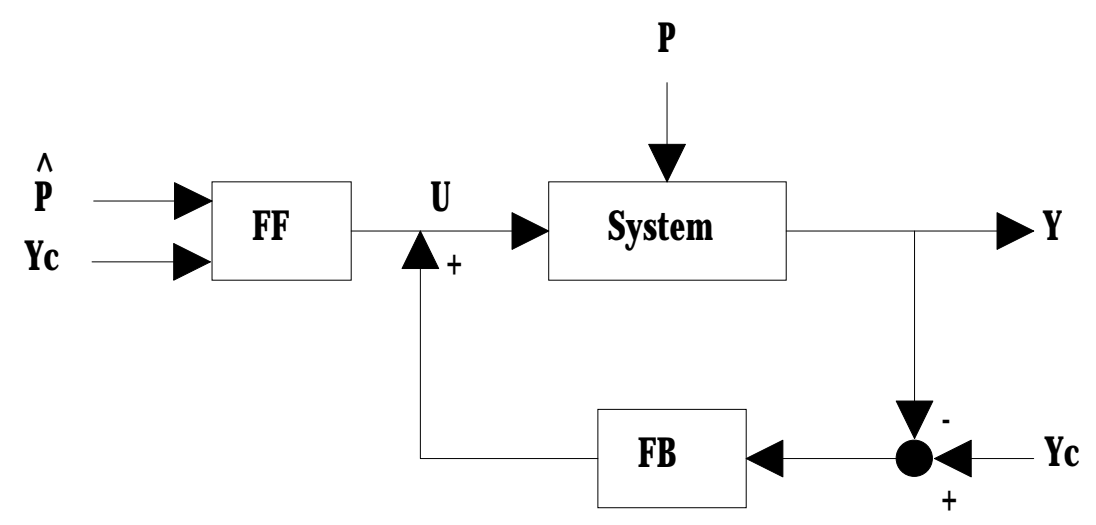

FIG. 6. Feedforward + feedback control. 


\section{Direction}

A structure can be operated to control a variable located further downstream, which is called downstream control (Figure 7). All variables (discharge, level or volume) can be controlled with downstream control. A structure can also be operated to control a variable located further upstream, which is called upstream control (Figure 8). Only levels or volumes can be controlled with upstream control, when flow conditions are subcritical and under the limitations of the backwater effects. This limitation explains why downstream control is a very interesting method compared to upstream control.

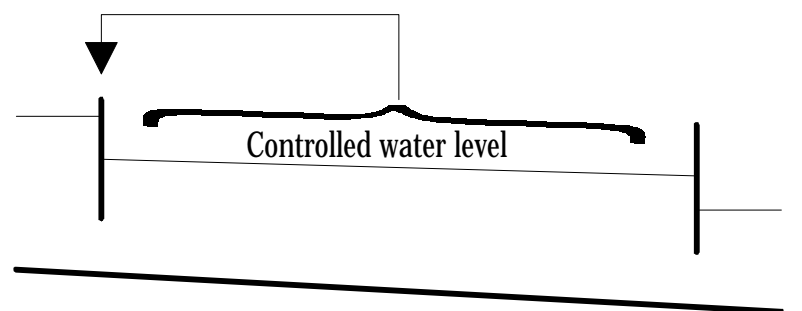

FIG. 7. Downstream control.

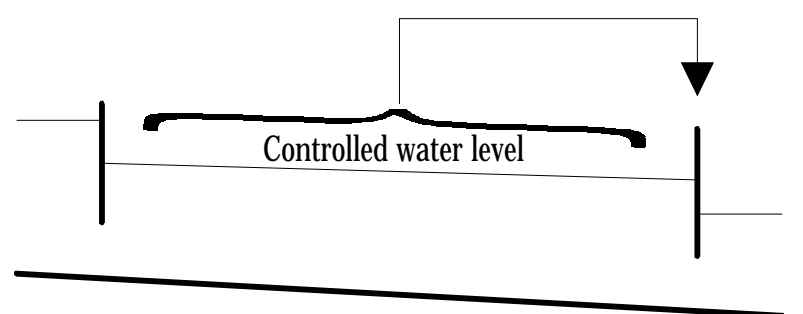

FIG. 8. Upstream control.

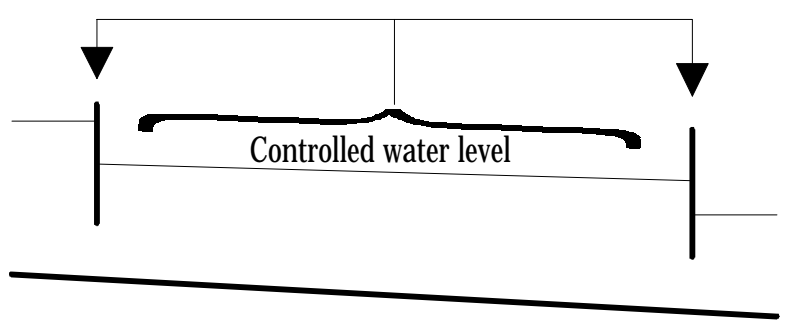

FIG. 9. Mixed control.

Examples of downstream control methods are AVIS, AVIO gates, LittleMan downstream, ELFLO (Shand 1971), CARDD (Burt 1983), Zimbelman (1981), CARA (Marzouki 1989), BIVAL, PI developed by Sogreah, PID (Chevereau 1991), PIR (Deltour 1992), Liu et al. 1994, Dynamic Regulation (SCP) and Controlled Volumes (USBR).

Examples of upstream control methods are AMIL gate, LittleMan upstream, P+PR (Buyalski 1977), PID developed by UMA Engineering.

Some control methods combine upstream and downstream control logics (Figure 9). They are sometimes called mixed controls. Since they benefit from the main advantages of downstream control methods, they are often called, to simplify, downstream control methods. Examples of such methods are LQR (Corriga et al. 1980, 1982a, 1982b and 1983, Balogun 1985 and 1988, Garcia 1988 and 1992, Hubbard et al. 1987, Reddy 1986, 1990, 1992a and 1992b, Filipovic et al. 1989, Florea et al., Malaterre 1994 and 1995b, Sawadogo et al. 1994), and Mixed gates (GEC Alsthom, used by the CNABRL). The latter are sometimes designated as "associated levels gates", because, in certain hydraulic conditions, the purpose of the gate is to maintain a constant difference between its upstream and downstream water levels. We consider this gate as a "mixed control" gate, because modification of a water level in a pool implies the combined reaction of the two gates located upstream and downstream from this water level. 


\section{DESIGN TECHNIQUES}

Control theory implies a three step process: 1) system modeling (i.e. the definition of a model), 2) system analysis (i.e. the study of the model behavior), and 3) controller design. The design technique is the algorithm or methodology used within the control algorithm in order to generate the control action variables from the measured variables.

Main design techniques examples are heuristic, three position, PID, pole placement, predictive control, optimal control, fuzzy control, neural network, backward simulation, linear optimization, and non-linear optimization.

Additional components: a main technique can benefit from additional components that may improve control algorithm performance by accounting for canal system features. Examples are filter, decoupler, observer, Smith predictor, and autoadaptative tuning.

Design techniques can be split into two main categories, usually requiring different mathematical backgrounds: monovariable and multivariable methods.

\section{Monovariable methods}

Heuristic monovariable methods have been developed based on hydraulics and not on control theory (e.g. Zimbelman (1987), CARDD (Burt 1983)). Although quoted in the literature, these methods are too site specific and have not been implemented on operating canals. An empirical method used by CARA on river-pond systems (Marzouki 1989) is being modernized (Roux 1992). BIVAL and LittleMan (USBR, Buyalski 1991) are methods based on a three position controller.

Most of the irrigation canal control methods based on control theory use the well-known linear monovariable PID controller. This PID controller can be tuned with the Ziegler-Nichols method or by pole placement (Larminat 1993, Aström et al. 1993). Examples of PID related methods are:

- P: AMIL, AVIS, AVIO,

- PI: ELFLO, P+PR, Dynamic Regulation, PI Sogreah,

- PID: PID UMA Engineering.

Although very efficient in most cases, PID controllers do not explicitly take into account the characteristic canal time delays. Shand (1971) prospected the possibility to use a Smith Predictor in order to overcome this problem, when studying the automation of Corning Canal, California, USA. Developing an analog dead time model raised technological difficulties. Therefore, though less efficient, ELFLO method was eventually selected. Recently, the combination of a PI controller with a Smith Predictor was further developed (Deltour 1992, Sanfilippo 1993). This controller is called PIR. Modern digital technology has solved problems faced by Shand.

Other linear controllers have been used on river systems with long time delays by CACG. High order transfer functions are used, and tuned with the pole placement technique.

The generalized predictive control method (GPC), a monovariable optimization method, has been developed by Sawadogo (1992) and Rodellar (1993). It is not based on the desired feedback control behavior, but on the minimization of a criterion $\mathrm{J}$, pondering the control action variable and the error between the controlled variable and its targeted value. GPC method uses transfer function models 
(Chan et al. 1990, Soeterboek 1990, Lee et al. 1990, Linkens et al. 1992). It naturally incorporates a feedforward and a feedback control.

Methods based on fuzzy control (e.g. CNABRL on the T2 and on the CPBS canals, Morocco, Bouillot 1994), expert systems, or neural networks (e.g. Schaalje et al. 1993, Toudeft 1994) are being developed. The two latest methods are still prospective, and should be tested.

Monovariable methods require splitting the system into several subsystems without taking explicitly into account interactions between them. An irrigation canal is a multivariable system presenting strong interactions between subsystems. For example, the operation of a gate influences several upstream and downstream pools. The decoupler technique has been applied to the ELFLO controller (Schuurmans 1992). It restrains, as far as possible, the influence of one control action on the unique regulator-controlled output. The global multivariable process can then be considered as a series of independent monovariable non-interactive processes evolving in parallel. This is possible if the number of inputs is greater than or equal to the number of outputs (Borne et al. 1990). Performance of a controller can be greatly improved through decoupling. Decoupling requires a linear model of the system. Its performance is therefore decreased due to unknown perturbations and model errors. Although PIR (Deltour 1992), and Dynamic Regulation do not consider coupling effects explicitly, they attempt to reduce these effects. The discharge and not the gate position is chosen as the control action variable, which is similar to decoupler II of Schuurmans (1992). Furthermore, part of the gate control action is transferred to the previous upstream controller, which is similar to decoupler I of Schuurmans (1992).

\section{Multivariable methods}

Control engineers have developed several multivariable methods. However, very few of them have been used on canals. For example, pole placement technique in state space and multivariable PID have never been applied to irrigation canal regulation.

Different model inversion methods are described in the literature, leading generally to feedforward controllers (Chevereau 1991, Liu et al. 1992), and more rarely to feedback controllers (Liu et al. 1994).

Optimization methods have also been developed. These methods are, in essence, multivariable. Different methods exist: linear optimization (Sabet 1985), non-linear optimization (Tomicic 1989, Khaladi 1992, Lin 1992), and LGR (Corriga 1983, Florea, Balogun 1985, Hubbard 1987, Garcia 1988, Filipovic 1989, Reddy 1992, Malaterre 1994, Kosuth 1994, Sawadogo et al. 1994). The classical nonlinear optimization leads solely to a feedforward control, sensitive to errors and perturbations. In order to introduce a feedback control, the optimization has to be processed periodically (for example at each time step). This complicates the method and limits its applications due to real-time constraints. Furthermore, the determination of real initial conditions, required for the optimization, is not easy. On the other hand, LQR methods, based on a state space representation, can incorporate, in essence, a feedforward control and a feedback control.

The implementation of multivariable methods is far more complex than for monovariable methods. 


\section{CONCLUSION}

This paper presents a clear structure for characterizing each control algorithm according to a series of defined criteria (Considered variables, Logic of control, Design technique). The advantage of this structure is to allow the comparison of different algorithms' characteristics and to make classification of them according to a selected criteria.

Canal control algorithms detailed in the literature are classified in Table 1. They are listed according to their main design technique (e.g. heuristic or PID). However, some data are missing, due to the lack of clarity of the available literature. In addition to information relative to the three criteria, the developer name and examples of application or test are given.

Complete references can be found in Zimbelman 1987, Goussard 1993 or Malaterre 1994 and 1995a. Additional and updated information on canal regulation is available on the CANARI World Wide Web Server at the internet address: http://www.montpellier.cemagref.fr/ pom/canari.htm.

Such characterizations and classifications are useful to get a better understanding of the features and properties of each regulation method. Indeed, the characteristics of each regulation method will have corresponding advantages, disadvantages, performance and constraints. Canal operators and engineers should find these classifications useful to determine appropriate regulation methods for specific installations.

\section{APPENDIX I. REFERENCES}

GEC Alsthom. 1975-1979. Notice de montage, réglage et entretien des vannes AMIL, AVIS, AVIO. 100 p.

GEC Alsthom. 1981. Gestion de canaux et irrigation. Les matériels NEYRTEC d'équipement pour réseaux régulés. $40 \mathrm{p}$.

Aström, K.J. and Hägglund, T. 1993. PID Control. Personnal communication of a draft version, to be published.

Balogun, O.S, Hubbard, M. and DeVries, J.J. 1988. Automatic control of canal flow using linear quadratic regulator theory. Journal of Hydraulic Engineering, Vol. 114, $\mathrm{n}^{\circ}$ 1, pp 75-102.

Balogun, O.S. 1985. Design of real-time feedback control for canal systems using linear quadratic regulator theory. $\mathrm{PhD}$ thesis, Department of Mechanical Engineering, University of California at Davis, $230 \mathrm{p}$.

Barbet, P. 1990. Modèle standard de simulation du fonctionnement des systèmes hydrauliques BarrageRivière. Application à la gestion des lâchures. Cemagref, ENITRTS, 106 p.

Baume, J.-P., Sally, H., Malaterre, P.O. and Rey, J. 1993. Development and field-installation of a mathematical simulation model in support of irrigation canal management. IIMI and Cemagref Research paper, 89 p.

Borne, P., Dauphin-Tanguy, G., Richard, J.-P., Rotella, F. and Zambettakis, I. 1990. Commande et optimisation des processus. Editions Technip, 15ème Paris, 303 p.

Bouillot, A.-P. 1994. Application of the fuzzy set theory to the control of a large canal. ASCE - AFEID Meeting, October 1994, Aix-en-Provence, France, 25 p. 
Burt, C.M. 1983. Regulation of sloping canals by automatic downstream control. PhD, Utah State University.

Buyalski, C. P. 1977. Study of an automatic upstream control system for canals. Publ. GR-78-4, Bureau of Reclamation, Denver CO, 79 p.

Buyalski, C.P. and Serfozo, E.A. 1979. Electronic filter level offset (EL-FLO) plus reset equipment for automatic downstream control of canals. Technical Report REC-ERC-79-3, U.S. Department of Interior, Bureau of Reclamation, Denver Office, 145 p.

Buyalski, C.P., Ehler, D. G., Falvey, H. T., Rogers, D. C., and Serfozo, E. A. 1991. Canal systems automation manual, Volume 1. A Water Resources Technical Publication, U.S. Department of Interior, Bureau of Reclamation, Denver Office, 113 p.

Chan, S.P. and Yao, B. 1990. Performance study of GPC for processes with time delay. IEEE, pp 384389.

Chavez, A.A., Gonzalez, E.P., Kosuth, P., Daval, E. 1994. Informe final del proyecto automatizacion de canales SH 9408. IMTA, Cemagref, CNA, 83 p.

Chevereau, G. 1991. Contribution à l'étude de la régulation dans les systèmes hydrauliques à surface libre. Thèse de Doctorat de l'Institut National Polytechnic de Grenoble, 122 p.

Coeuret, C. 1977. Stabilité et précision de la régulation dynamique. La Houille Blanche $n^{\circ} 2 / 3$, pp 272277.

Corriga, G., Fanni, A., Sanna, S. and Usai, G. 1982a. A constant-volume control method for open channel operation. International Journal of Modelling and Simulation, Vol 2, n 2, pp 108-112.

Corriga, G., Sanna, S. and Usai, G. Centralized control of irrigation canal systems. Unknown date and source, pp 69-83.

Corriga, G., Sanna, S. and Usai, G. 1980. Frequency response and dynamic behaviour of canal networks with self-levelling gates. Appl. Math. Modelling, Vol. 4, pp 125-129.

Corriga, G., Sanna, S. and Usai, G. 1982b. Sub-optimal level control of open-channels. Proceedings International AMSE conference Modelling and Simulation, Vol. 2, pp 67-72.

Corriga, G., Sanna, S. and Usai, G. 1983. Sub-optimal constant-volume control for open channel networks. Appl. Math. Modelling, Vol. 7, pp 262-267.

De Leon Mojarro, B. 1986. Contribution à l'amélioration de la gestion des périmètres irrigués. Thèse de Doctorat, USTL Montpellier, 137 p.

De Leon Mojarro, B., Kosuth, P., Argueta, J. 1992. Use of the SIC simulation model to improve the management of an irrigation canal in la Begoña, Guanajuato, Mexico. Cemagref-IIMI International Workshop, Montpellier, October 1992, pp 173-187.

Deltour, J.-L. 1988. La régulation des systèmes d'irrigation. DEA, Ecole Nationale Supérieure d'Hydraulique de Grenoble, 87 p.

Deltour, J.-L. 1992. Application de l'automatique numérique à la régulation des canaux ; Proposition d'une méthodologie d'étude. Thèse de Doctorat, Institut National Polytechnic de Grenoble, 153 p.

Falvey, H.T. 1987. Philosophy and implementation of Gate Stroking. Proceedings ASCE Portland, Zimbelman D.D. (ed.), pp 176-179.

Filipovic, V. and Milosevic, Z. 1989. Dyn² method for optimal control of water flow in open channels. Journal of irrigation and drainage engineering, Vol. 115, $\mathrm{n}^{\circ} 6$, pp 973-981. 
Florea, J. and Popa, R. Optimal operation of an irrigation canal system for unsteady flow conditions. Unknown date and source, pp 33-45.

Framji, K.K. and Verdier, J. 1978. Etat de l'art $n^{\circ} 1$ : Irrigation, drainage et maîtrise des crues ; Chapitre 9 : L'automatique dans l'irrigation, pp 459-578. ICID, New Delhi, 676 p.

Garcia, A. 1988. Control and regulation of open channel flow. Master of Science, University of California, Davis, 232 p.

Garcia, A., Hubbard, M. and DeVries, J.J. 1992. Open channel transient flow control by discrete time LQR methods. Automatica, Vol. 28, n 2, pp 255-264.

Goussard, J. 1993. Automation of canal irrigation systems. International Commission of Irrigation and Drainage, Working Group on Construction, Rehabilitation and Modernization of Irrigation Project, ICID, $103 \mathrm{p}$.

Grosclaude, J.-Y. and Tardieu, H. 1985. La gestion automatique des eaux d'étiage - Description et premiers résultats. Unknown source, pp 35-39.

Hubbard, M., DeVries, J.J. and Balogun, O.S. 1987. Feedback control of open channel flow with guaranteed stability. AIRH Congress, pp 408-413.

Hurand, P. and Kosuth, P. 1993. Régulations en rivière. La Houille Blanche, n² 2/3 1993, pp 143-149.

Khaladi, A. 1992. Gestion automatique des transferts d'eau en réseaux hydrauliques maillés à surface libre ; Application au réseau des Wateringues. Thèse de Doctorat, Ecole Centrale de Lyon, Cemagref, 237 p.

Kosuth, P., Roux, A., Lafaysse, J.L. 1992. Use of a simulation model to improve operation of dam-river systems for irrigation purpose: elements for a methodology. Cemagref-IIMI International Workshop, Montpellier, October 1992, pp 81-90.

Kosuth, P. 1994. Technics de régulation automatique des systèmes complexes : application aux systèmes hydrauliques à surface libre. Thèse de Doctorat, Institut National Polytechnic de Toulouse Cemagref - LAAS CNRS, 330 p.

Kuanyi, Z. 1989. Contribution à l'automatisation de processus à temps mort. Thèse de Doctorat de l'Université Catholique de Louvain, 168 p.

Larminat, P. 1993. Automatique, Commande des systèmes linéaires. Hermès, 321 p.

Lee, T.H., Lai, W.C. and Kwek, K.H. 1990. Extended generalised predictive control incorporating feedforward. pp 2703-2708. Unknown source.

Lefebvre, J. 1977. La régulation dynamique, sa mise en oeuvre au canal de provence. La Houille Blanche, $n^{\circ} 2 / 3$, pp 265-270.

Lin, Z. and Manz, D.H. 1992. Optimal operation of irrigation canal systems using nonlinear programming - dynamic simulation model. Cemagref-IIMI International Workshop, Montpellier, October 1992, pp 297-306.

Linkens, D.A. and Mahfouf, M. 1992. Generalized predictive control with feedforward (GPCF) for multivariable anaesthesia. Int. J. Control, Vol 56, n 5, pp 1039-1057.

Liu, F., Feyen, J. and Berlamont, J. 1992. Computation method for regulating unsteady flow in open channels. Journal of irrigation and drainage engineering, Vol. 118, n 10, pp 674-689.

Liu, F., Feyen, J. and Berlamont, J. 1994. Downstream control algorithm for irrigation canals. Journal of irrigation and drainage engineering, Vol. 120, $\mathrm{n}^{\circ} 3$, pp 468-483. 
Malaterre, P.O. 1989. Etude des possibilités d'amélioration des règles de gestion manuelle du canal principal rive droite de Kirindi Oya grâce à un modèle mathématique de simulation des écoulements. Cemagref, ENGREF, IIMI, DEA National d'Hydrologie USTL Montpellier, $121 \mathrm{p}$.

Malaterre, P.O. 1994. Modelisation, Analysis and LQR Optimal Control of an Irrigation Canal. PhD Thesis LAAS-CNRS-ENGREF-Cemagref, Etude EEE n 14, ISBN 2-85362-368-8, 255 references, 220 p.

Malaterre, P.O. 1995a. Regulation of irrigation canals: characterisation and classification. International Journal of Irrigation and Drainage Systems, Vol. 9, n4, November 1995, p. 297-327.

Malaterre, P.O. 1995b. PILOTE: optimal control of irrigation canals. First International Conference on Water Resources Engineering, Irrigation and Drainage, San Antonio, Texas, USA, 14-18 August 1995.

Marzouki, T.Z. 1989. Le système hydraulique de la rivière larcis (barrages, rivière, périmètres irrigués). Modélisation hydraulique, analyse et amélioration de la gestion. Cemagref, ENGREF, CARA, 63 p.

Najim, K. 1981. Application des automates à structure variable à la commande d'un canal d'irrigation. Automatique Systems analysis and control, Vol. 15, n³, pp 263-270.

O'Loughlin, E.M. 1972. Application of unsteady flow analysis to operation decisions in long aqueducts. R. 16, Q. 28-2, VIIIth ICID Congress, Bulgaria.

Perrin, G. 1989. Automatisation d'un système d'irrigation à gestion centralisée. Conservatoire National des Arts et Métiers, Centre Régional Associé de Metz, 154 p.

Piquereau, A., Tardieu, H., Verdier, J. and Villocel, A. 1984. Réduction des pertes en eau par l'automatisation de la gestion d'un barrage realimentant une rivière en vue de l'irrigation. Communication au XIIème congrès de la CIID, 16 p.

Piquereau, A. and Villocel, A. 1982. Gestion automatique des eaux d'étiage ; Cas de la rivière Arrats. ONERA, CERT/DERA Toulouse, CACG, 125 p.

Reddy, J.M. 1986. Evaluation of optimal constant volume control for irrigation canals. ASAE, 14 p.

Reddy, J.M. 1990. Local optimal control of irrigation canals. Journal of Irrigation and Drainage Engineering, Vol. 116, $\mathrm{n}^{\circ}$ 5, pp 616-631.

Reddy, J.M. 1992a. Decentralized constant-volume control of irrigation canals. Proceedings "Advances in Planning, Design and Management of Irrigation Systems as Related to Sustainable Land Use". Leuven, 14-17 September 1992, Feyen et al. (Ed), pp 889-898.

Reddy, J.M., Dia A. and Oussou A. 1992b. Design of control algorithm for operation of irrigation canals. Journal of Irrigation and Drainage Engineering, Vol. 118, $\mathrm{n}^{\circ}$ 6, pp 852-867.

Rey, J. 1990. Contribution à la modélisation et la régulation des transferts d'eau sur des systèmes de type rivière/bâches intermédiaires. Cemagref, ENGREF, DEA National d'Hydrologie USTL Montpellier, $80 \mathrm{p}$.

Rodellar, J., Gomez, M. and Bonet, L. 1993. Control method for on-demand operation of open-channel flow. Journal of Irrigation and Drainage Engineering, Vol. 119, n 2, pp 225-241.

Rogers, D. C., Ehler, D. G., Falvey, H. T., Serfozo, E. A., Voorheis, P., Johansen, R. P., Arrington, R. M. and Rossi, L. J. 1995. Canal systems automation manual, vol. 2. Bureau of Reclamation, Denver CO, 236 p. 
Roux, A. 1992. Gestion des étiages de rivière par les méthodes de l'automatique. Application à la rivière Dropt. Cemagref, ENITRTS, 177 p.

Sabet, M.H., Coe, J.Q., Ramirez, H.M. and Ford, D.T. 1985. Optimal operation of California Aqueduct. Journal of Water Resources Planning and Management, Vol. 111, n² 2, pp 222-237.

Sanfilippo, F. 1993. Application du régulateur PIR au cas des canaux à forte pente. DEA de l'Université Claude Bernard, Lyon 1, 137 p.

Sawadogo, S. 1992a. Modélisation, commande prédictive et supervision d'un système d'irrigation. Thèse de Doctorat, LAAS-CNRS Toulouse, $152 \mathrm{p}$.

Sawadogo, S., Achaibou, A.K. and Aguilar-Martin, J. 1991a. An application of adaptative predictive control to water distribution systems. IFAC, ITAC 91, Singapour, 6 p.

Sawadogo, S., Achaibou, A.K. and Aguilar-Martin, J. 1992b. Long-range predictive control of an hydraulic systems. Cemagref-IIMI Workshop, 9 p.

Sawadogo, S., Achaibou, A.K., Aguilar-Martin, J. and Mora-Camino, F. 1991b. Output tracking by inverse adaptive control: application to water distribution systems. IMACS IFAC, Lille, Proceedings, Vol 1, pp 88-93.

Sawadogo, S., Achaïbou, A.K., Aguilar-Martin, J. and Mora-Camino, F. 1992c. Intelligent control of large water distribution systems: a two level approach. SICICI 92, Singapour, Proceedings, pp 1085-1089.

Sawadogo, S., Malaterre, P.O. and Kosuth, P. 1995. Multivariable optimal control for on-demand operation of irrigation canals. The International Journal of Systems Science, Vol 26:1, p 161-178.

Schaalje, M. and Manz, D.H. 1993. ANN controller. Personal communication.

Schuurmans, J. 1992. Controller Design for a Regional Downstream Controlled Canal. Delft University of Technology, Laboratory for Measurement and Control, $100 \mathrm{p}$.

Shand, M.J. 1971. Automatic downstream control systems for irrigation canals. PhD, University of California, Berkeley, 159 p.

Shinskey, F.G. 1988. Process control systems, Application, Design, and Tuning. McGraw-Hill Publishing Company, New York, 526 p.

Soeterboek, R. 1990. Predictive control: a unified approach. PhD, Delft University of Technology, 358 p.

Tardieu, H. 1988. Automatic dam management and river regulation for irrigation purposes. Irrigation and Drainage Systems, $\mathrm{n}^{\circ} 2$, pp 53-61.

Tomicic, B. 1989. A general optimization module for real-time control of surface water resources. Master of Science, The International Institute for Hydraulic and Environmental Engineering, Delft University, $174 \mathrm{p}$.

Toudeft, A., Kosuth, P. and Gallinari, P. 1994. A PID Neural Controller for Unstable Delayed Linear Systems. ICANN'94 Proceedings. University of Salerno, Italy, 4 p.

Trouvat, J.-L. 1991. Contribution à une meilleure gestion des rivières de Gascogne. Cemagref, CACG, ENGREF, $61 \mathrm{p}$.

USBR. 1979. Gate Stroking. Internal paper, $15 \mathrm{p}$.

Verdier, J. 1986. Informatisation de la commande du transport et de la distribution d'eau d'irrigation. XIV Journées régionales européennes de la CIID, La Manga del Mar Menor (Espagne), 15 p.

Zimbelman, D.D. 1987. Planning, operation, rehabilitation and automation of irrigation water delivery systems. Proceedings of a symposium ASCE, Portland, Oregon, USA, 28-30 July 1987, 377 p. 


\section{APPE NDIX II. NOTATION}

The following symbols are used in this paper:

$\mathbf{G}=$ Regulator gate position;

$\mathbf{P}=$ Perturbation;

$\hat{\mathbf{P}}=$ Estimation of perturbations;

$\mathbf{Q}=$ Discharge in the canal;

$\mathbf{Q}_{\mathrm{dn}}=$ Downstream discharge in the canal;

$\mathbf{Q}_{\text {in }}=$ Intermediate discharge in the canal;

$\mathbf{Q}_{\mathrm{up}}=$ Upstream discharge in the canal;

$\mathbf{U}=$ Control action variable;

$\mathbf{V}=$ Volume in a canal pool;

$\mathbf{Y}=$ Controlled variable;

$\mathbf{Y}_{\mathrm{c}}=$ Target controlled variable;

$\mathbf{y}=$ Water elevation;

$\mathbf{y}_{\mathrm{dn}}=$ Downstream water elevation of the pool (therefore upstream of a regulator);

$\mathbf{y}_{\text {in }}=$ Intermediate water elevation in the pool;

$\mathbf{y}_{\mathrm{up}}=$ Upstream water elevation of the pool (therefore downstream of a regulator);

$\mathbf{Z}=$ Measured variable.

\section{APPENDIX III. ABBREVIATIONS}

The following abbreviations are used in this paper:

ASCE = American Society of Civil Engineers;

CACG = Compagnie d'Aménagement des Coteaux de Gascogne;

CARA = Compagnie d'Aménagement Rural d'Aquitaine;

CARDD = Canal Automation for Rapid Demand Deliveries;

Cemagref = La recherche pour l'ingénierie de l'agriculture et de l'environnement;

CNABRL = Compagnie Nationale d'Aménagement du Bas-Rhône Languedoc;

ELFLO = Electronic Filter Level Offset;

$\mathbf{F B}=$ Feedback or closed-loop control;

$\mathbf{F F}=$ Feedforward or open-loop control;

GPC = Generalized Predictive Control;

LQR = Linear Quadratic Regulator, also called Optimal Control;

MIMO = Multiple Inputs, Multiple Outputs;

nImO = n Inputs, $\mathrm{m}$ Outputs;

PID = Proportional, Integral, Derivative Controller;

PIR = Contrôleur Proportionnel, Intégral, Retard (PI delay controller);

SCP $=$ Société du Canal de Provence;

SISO $=$ Single Input, Single Output;

USBR = United States Bureau of Reclamation. 
Table 1. Classification of canal control algorithms.

\begin{tabular}{|c|c|c|c|c|c|c|c|c|c|}
\hline \multicolumn{2}{|c|}{ IDENTIFICATION } & \multicolumn{7}{|c|}{ CHARACTERIZATION } & \multirow{3}{*}{$\begin{array}{c}\text { APPLICATIONS } \\
\text { OR TESTS }\end{array}$} \\
\hline \multirow[t]{2}{*}{ Name } & \multirow[t]{2}{*}{ Developer } & \multicolumn{3}{|c|}{ Considered variables } & \multirow{2}{*}{$\begin{array}{c}\text { I/ } 0 \\
\text { Struc } \\
\text { t. } \\
\end{array}$} & \multicolumn{2}{|c|}{$\begin{array}{c}\text { Logic of } \\
\text { control } \\
\end{array}$} & \multirow[t]{2}{*}{ Design Technique } & \\
\hline & & \begin{tabular}{|c|} 
controll \\
ed
\end{tabular} & measured & $\begin{array}{l}\text { ctrl. } \\
\text { act. }\end{array}$ & & Type & Direct. & & \\
\hline CARDD & Burt \& Parrish & $\mathrm{y}_{\mathrm{dn}}$ & $3-5 y_{\text {in }}$ & G & $\begin{array}{l}3- \\
5 \mathrm{ISO} \\
\end{array}$ & FB & dn & Heuristic & CalPoly scale canal, USA \\
\hline \multirow[t]{3}{*}{ RTUQ } & Rogers & $\mathrm{Q}$ & $\mathrm{y}_{\text {up }} \mathrm{y}_{\mathrm{dn}} \& \mathrm{G}$ & $\mathrm{G}$ & 3 ISO & $\mathrm{FB}$ & $\mathrm{dn}$ & Heuristic & Dolores Project, USA \\
\hline & Zimbelman & $\mathrm{y}_{\mathrm{dn}}$ & $\mathrm{y}_{\mathrm{dn}}$ & $\mathrm{G}$ & SISO & FB & $\mathrm{dn}$ & Heuristic & Model \\
\hline & Najim & $\mathrm{y}$ & $\mathrm{y}$ & Q & $?$ & $\mathrm{FB}+\mathrm{FF}$ & & Variable structure & \\
\hline BIVAL & Sogreah & $f\left(y_{u p}, y_{d n}\right)$ & $\mathrm{y}_{\mathrm{up}} \& \mathrm{y}_{\mathrm{dn}}$ & G & $2 \mathrm{ISO}$ & $\mathrm{FB}$ & $\mathrm{dn}$ & 3 position & Mali, Mexico, etc. \\
\hline DACL & USWC Lab & $\mathrm{y}_{\mathrm{dn}}$ & $\mathrm{y}_{\mathrm{dn}}$ & G & SISO & $\mathrm{FB}$ & up & 3 position & \\
\hline LittleMan & $\begin{array}{|ll|}\text { USBR } & \text { and } \\
\text { others }\end{array}$ & $\mathrm{y}_{\mathrm{dn}}$ & $y_{\mathrm{dn}}$ & G & SISO & FB & up & 3 position & Several in USA \\
\hline AMIL & GEC Alsthom & $y_{\mathrm{dn}}$ & $\mathrm{y}_{\mathrm{dn}}$ & $\mathrm{G}$ & SISO & $\mathrm{FB}$ & up & $\mathrm{P}$ & Several countries \\
\hline AVIS, AVIO & GEC Alsthom & $y_{u p}$ & $\mathrm{y}_{\mathrm{up}}$ & G & SISO & $\mathrm{FB}$ & $\mathrm{dn}$ & $\mathrm{P}$ & Several countries \\
\hline Danaïdean system & & $y_{d n}$ & $\mathrm{y}_{\mathrm{dn}}$ & $\mathrm{G}$ & SISO & FB & up & $\mathrm{P}$ & Several in USA \\
\hline Mixed Gates & GEC Alsthom & $f\left(\mathrm{y}_{\mathrm{up}}, \mathrm{y}_{\mathrm{dn}}\right)$ & $\mathrm{y}_{\mathrm{up}} \& \mathrm{y}_{\mathrm{dn}}$ & G & 2ISO & $\mathrm{FB}$ & up & $P$ & Several countries \\
\hline \multirow[t]{3}{*}{ Dynamic Regulation } & SCP - Gersar & $\mathrm{V}$ & $\mathrm{y}_{\mathrm{up}} \mathrm{y}_{\mathrm{dn}} \& \mathrm{G}$ & $\mathrm{Q}$ & 3 ISO & $\mathrm{FB}+\mathrm{FF}$ & $\mathrm{dn}$ & PI & France, Morocco \\
\hline & $\begin{array}{l}\text { IMTA } \\
\text { Cemagref } \\
\end{array}$ & $\mathrm{y}_{\mathrm{dn}}$ & $\mathrm{y}_{\mathrm{dn}}$ & Q & SISO & $\mathrm{FB}+\mathrm{FF}$ & $d n$ & PI & Begonia (Mexico) \\
\hline & \begin{tabular}{|l} 
UMA \\
Engineering \\
\end{tabular} & $\mathrm{y}_{\mathrm{dn}}$ & $\mathrm{y}_{\mathrm{dn}}$ & G & SISO & FB & up & PI & Imperial Valley, USA \\
\hline
\end{tabular}




\begin{tabular}{|c|c|c|c|c|c|c|c|c|c|}
\hline \multirow[t]{2}{*}{ ELFLO / P+PR } & $\begin{array}{l}\text { Buyalski, } \\
\text { Serfozo }\end{array}$ & $\mathrm{y}_{\mathrm{dn}}$ & $y_{\mathrm{dn}} \& \mathrm{G}$ & $G$ & $2 \mathrm{ISO}$ & FB & dn & PI + filter & Several in USA \\
\hline & Sogreah & $\mathrm{y}_{\mathrm{dn}}$ & $y_{d n}$ & $\mathrm{G}$ & SISO & $\mathrm{FB}+\mathrm{FF}$ & $\mathrm{dn}$ & PI + filter & Kirkuk (Iraq) \\
\hline & $\begin{array}{l}\text { CARA } \\
\text { Cemagref } \\
\end{array}$ & $Q_{\mathrm{dn}}$ & $Q_{\mathrm{dn}}$ & $\mathrm{Q}_{\mathrm{up}}$ & SISO & $\mathrm{FB}+\mathrm{FF}$ & $d n$ & PID + heuristic & $\begin{array}{l}\text { Rivers, South West of } \\
\text { France }\end{array}$ \\
\hline MODUVAR $^{\circledR} 32$ & GEC Alsthom & $\mathrm{y}_{\mathrm{up}}$ or $\mathrm{y}_{\mathrm{dn}}$ & $\mathrm{y}_{\mathrm{up}}$ or $\mathrm{y}_{\mathrm{dn}}$ & G & $\begin{array}{l}1- \\
2 \mathrm{ISO} \\
\end{array}$ & FB & $\begin{array}{ll}\text { up } \\
\text { dn }\end{array}$ & PID & France \\
\hline PIR & SCP - Gersar & $\mathrm{y}_{\mathrm{dn}}$ & $\mathrm{y}_{\mathrm{dn}}$ & Q & 2ISO & $\mathrm{FB}$ & $\mathrm{dn}$ & PI + Smith predictor & France (SCP) \\
\hline \multirow{2}{*}{ CARAMBA } & Sawadogo & $Q_{d n}$ & $Q_{\mathrm{dn}}$ & $\mathrm{Q}_{\mathrm{up}}$ & SISO & $\mathrm{FB}+\mathrm{FF}$ & $\mathrm{dn}$ & GPC & Non linear model \\
\hline & $\begin{array}{l}\text { Rodellar, } \\
\text { Gomez }\end{array}$ & $\mathrm{Q}_{\mathrm{dn}}$ & $\mathrm{Q}_{\mathrm{dn}}$ & $\mathrm{B}_{\mathrm{up}}$ & SISO & FB & dn & Predictive control & Non linear model \\
\hline \multirow[t]{3}{*}{$\begin{array}{l}\text { Model } \\
\text { Control } \\
\end{array}$} & $\begin{array}{l}\text { Zagona } \\
\text { Clough }\end{array}$ & Q \& y & Q \& y & G & MIMO & $\mathrm{FB}+\mathrm{FF}$ & $d n$ & Predictive control & Model \\
\hline & Corriga & $\mathrm{y}$ & $\mathrm{y}_{\mathrm{up}} \& \mathrm{y}_{\mathrm{dn}}$ & G & MIMO & $\mathrm{FB}$ & up & LQR + observer & Non linear model \\
\hline & Davis U. & Q \& y & $\mathrm{y}_{\mathrm{up}} \& \mathrm{y}_{\mathrm{dn}}$ & Q \& G & MIMO & FB & $\begin{array}{l}\text { up } \\
\mathrm{dn}\end{array}$ & LQR + observer & Non linear model \\
\hline PILOTE & Cemagref & $\mathrm{y}_{\mathrm{dn}}(\& \mathrm{Q})$ & $\mathrm{y}_{\mathrm{un}} \& \mathrm{y}_{\mathrm{dn}}$ & $\mathrm{Q}_{\mathrm{up}} \& \mathrm{G}$ & MIMO & $\mathrm{FB}+\mathrm{FF}$ & up & LQR + observer & Non linear model \\
\hline
\end{tabular}




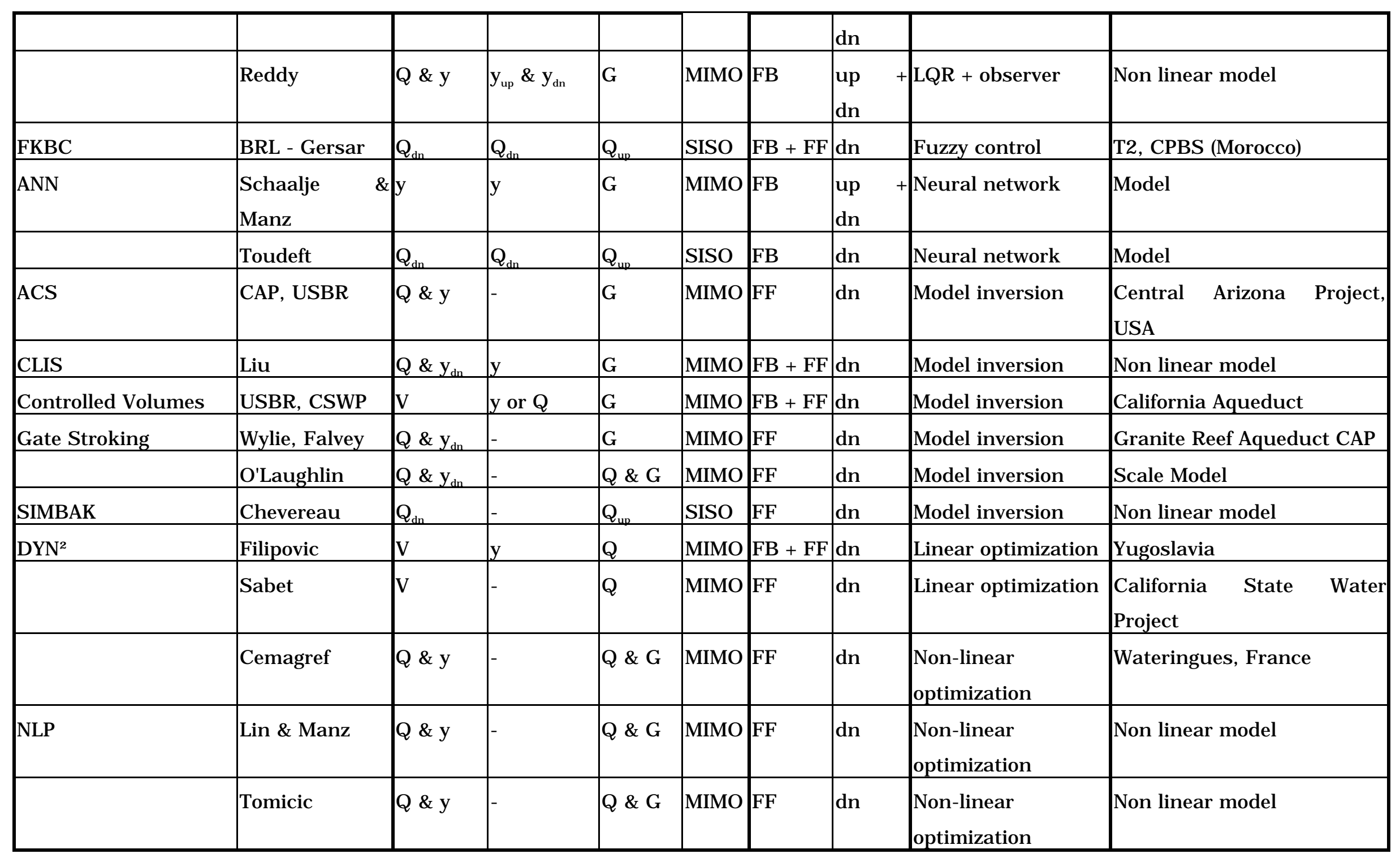

